\title{
Arah Dan Strategi Pengembangan Wisata Desa Sekotong Barat - Kabupaten Lombok Barat
}

\author{
Lukman Hakim*, Endang Astuti, Tuti Handayani \\ Fakultas Ekonomi dan Bisnis - Universitas Mataram \\ *Coresponding Email: lukmanomenghakim@gmail.com
}

\section{Info Artikel}

\section{Kata Kunci:}

Obyek wisata, analisa

SWOT, analisa Model

Diamond

\section{ABSTRAK}

Kajian riset guna merumuskan strategi yang diperlukan untuk pengembangan wisata, lazimnya menggunakan analisis SWOT. Beberapa diantaranya adalah penelitian yang dilakukan oleh Satriawati, dkk (2019); Susanto dan Amin Kiswantoro (2019); Suprina dan A. Amanda Nathania (2018); maupun oleh Salam, dkk (2018). Namun, dalam metode analisanya tidak menunjukkan adanya suatu hasil berupa indeks dari SWOT - suatu besaran/angka yang menentukan koordinat kuadran strategi, sebagai dasar utama dalam merumuskan strategi dan tingkat konfidensinya. Disamping itu, diadopsi Model Diamond dari Porter (Valiollahpour, et.al, 2014) untuk melengkapi analisa SWOT.

Riset bertujuan untuk menentukan arah dan strategi pengembangan wisata, serta mengidentifikasi obyek wisata unggulan di desa penelitian berdasarkan bauran pendekatan tersebut.

Hasil analisa menunjukkan bahwa arah pengembangan wisata Desa Sekotong Barat adalah wisata bahari, dengan obyek wisata unggulan pada obyek wisata renang. Strategi pengembangan pariwisata desa bersifat agresif. 


\section{PENDAHULUAN}

Penelitian tentang pengembangan wisata dengan menggunakan analisis SWOT (kekuatan, kelemahan, kesempatan, dan ancaman) telah banyak dilakukan. Beberapa diantaranya adalah penelitian yang dilakukan oleh Satriawati, dkk (2019); Susanto dan Amin Kiswantoro (2019); Suprina dan A. Amanda Nathania (2018); maupun oleh Salam, dkk (2018). Namun, dalam metode analisanya tidak menunjukkan adanya suatu hasil berupa indeks dari SWOT - suatu besaran/angka dan koordinatnya, sebagai dasar utama dalam merumuskan strategi dan tingkat konfidensinya. Selain itu, strategi yang ditawarkan, arah pengembangannya tidak berlandaskan pada suatu konsep pengembangan wisata. Salah satunya (relatif baru) adalah mengadopsi Model Diamond dari Porter guna menetapkan suatu obyek wisata unggulan dalam menentukan arah pengembangan desa wisata (Valiollahpour, et.al, 2014).

Dalam upaya pengembangan desa wisata, diperlukan adanya keterlibatan dari segenap unsur yang ada dalam masyarakat agar kesejahteraan masyarakat meningkat dan keberlanjutan desa wisata lebih terjamin. Sesuai dengan hal itu, Sukmana, dkk (2018); Rakhmat, dkk (2018); dan Hidayat, dkk (2017), mengamati keterlibatan beberapa elemen dalam masyarakat. Kajian keterlibatan masyarakat dalam pariwisata dihubungkan dengan dampak wisata terhadap lingkungan, ekonomi dan sosialbudaya masyarakat setempat.

Dampak dari pengembangan obyek-obyek desa wisata, telah mampu meningkatkan perekonomian masyarakat. Beberapa penelitian yang menunjukkan hal tersebut antara lain Vitriani, et.al (2017) yang mengatakan bahwa dampak positif lebih besar dari dampak negatif terhadap perubahan ekonomi-sosial masyarakat di Desa Sembalun Timur,
Provinsi Nusa Tenggara Barat. Selanjutnya Festivalia, dkk (2019) dengan menambahkan aspek lingkungan, mengungkapkan adanya dampak positif dari pariwisata terhadap ekonomi, sosial dan lingkungan di Desa Sumurugul, Provinsi Jawa Barat. Penelitian Hafida, dkk (2019) - relatif lebih rinci, dengan menghubungkan antara ketiga aspek (ekonomi, sosial-budaya, dan lingkungan) tersebut dan keberlanjutan desa wisata.

Berdasarkan penelusuran tersebut, belum terlihat adanya penelitian yang mengkaji pengkombinasian pendekatan SWOT dengan Model Diamond untuk menentukan arah dan strategi pengembangan. Kajian tentang hal demikian penting karena Model Diamond memetakan kondisi obyektif suatu obyek wisata. Sebagaimana dimaklumi, potensi dan keunikan obyek wisata berbeda antar wilayah/desa, sehingga dengan mengembangkan potensi obyek wisata tersebut menjadikannya 'diamond' dan unggul dibanding desa wisata lainnya. Dengan kata lain, arah pengembangan wisata tidak menduplikasi pengembangan wisata desa lain, yang akan memunculkan 'persaingan'. Perihal ini, penelitian yang dilakukan oleh Sari, dkk (2019), melihat perlunya mengeksplor sumberdaya pangan lokal sebagai wisata kuliner untuk meningkatkan daya saing desa wisata Sakerta Timur, Kabupaten Kuningan, Provinsi Jawa Barat.

\section{METODE PENELITIAN}

Penelitian berlokasi di Desa Sekotong Barat, Kabupaten Lombok Barat pada September 2020. Pengumpulan data dilakukan dengan pengisian angket dan wawancara mendalam (in-depth) terhadap 35 responden, terdiri dari Pokdarwis $\left(\mathrm{n}_{1}=15\right)$, aparat desa $\left(\mathrm{n}_{2}=5\right)$, tokoh masyarakat $\left(\mathrm{n}_{3}=5\right)$, dan pengusaha 
$\left(\mathrm{n}_{4}=10\right)$. Langkah pengumpulan data dan

berikut. analisa data digambarkan dalam bagan

\section{Bagan Rancangan Penelitian}

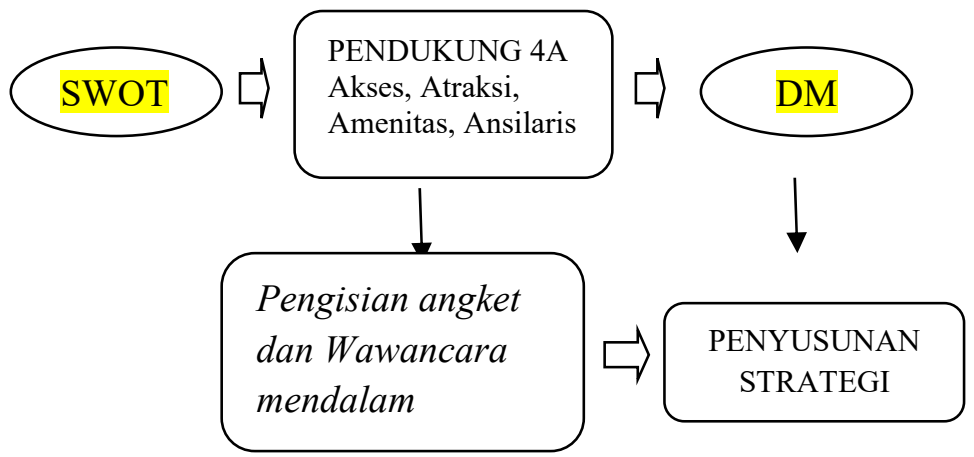

Analisis data dilakukan dengan bauran (mix) analisa kuantitatif dan kualitatif dengan unit analisis adalah desa wisata. Analisa kuantitatif menggunakan pendekatan SWOT (Rangkuti, 2009) untuk menilai terhadap 4 aspek, - dikenal dengan 4A, yaitu attraction (obyek wisata), amenity (fasilitas), accesibility (keterjangkauan), dan ancilliary (layanan tambahan). Pengembangan pariwisata dikaitkan pada aspek 4A ini (Cooper et al, 1993, dalam Satriawati, dkk, 2019), dengan aspek obyek wisata sebagai fokus dan lainnya sebagai pendukung. Hubugan keempat aspek tersebut digambarkan dalam bagan berikut.

\section{Bagan Hubungan 4A}

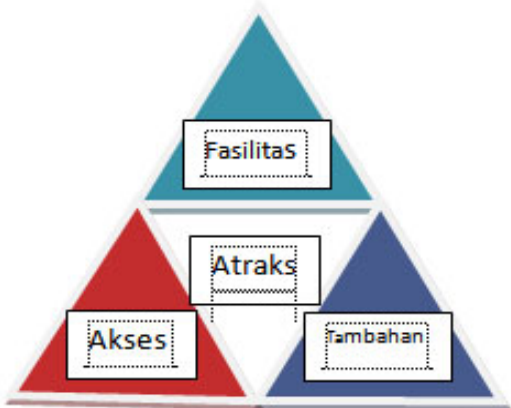

Analisis kualitatif menggunakan MD khususnya terhadap atraksi/obyek wisata, menyangkut kondisi/keadaan input (factors condition), kondisi/keadaan permintaan/pasar (demand conditions), dukungan industri (related and supporting industri), dan strategi dalam menghadapi persaingan (firm strategy, structure and rivalry).

Bagan Analisa Model Diamond

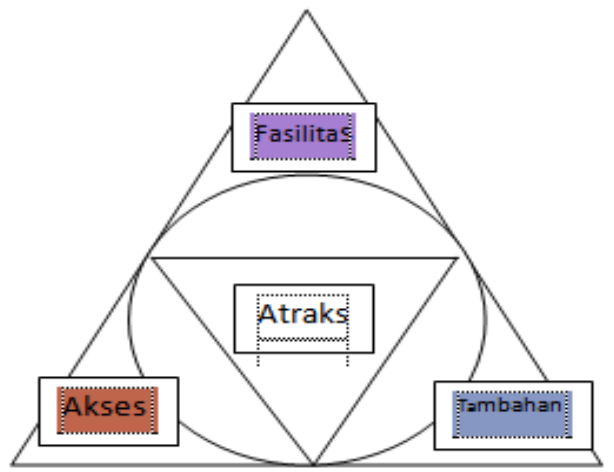

\section{HASIL DAN PEMBAHASAN}

Jenis obyek wisata di Desa Sekotong Barat adalah Obyek Wisata gili, Obyek Wisata renang, Obyek Wisata mancing, Obyek Wisata selam (diving), dan Obyek Wisata kemah (camping). 


\section{Elastisitas - Jurnal Ekonomi Pembangunan \\ Vol. 3 No. 2, September 2021}

Indeks skor SWOT dari obyek wisata yang terdapat di Desa Sekotong Barat ditunjukkan pada tabel berikut.

Tabel Indeks Obyek Wisata Desa Sekotong Barat

\begin{tabular}{|l|r|r|r|r|}
\hline $\begin{array}{c}\text { Obyek Wisata/ } \\
\text { Indeks skor SWOT }\end{array}$ & $\begin{array}{c}\text { Strength } \\
\text { Indeks skor }\end{array}$ & $\begin{array}{c}\text { Weakness } \\
\text { Indeks skor }\end{array}$ & $\begin{array}{r}\text { Opportunity } \\
\text { Indeks skor }\end{array}$ & $\begin{array}{c}\text { Threat } \\
\text { Indeks skor }\end{array}$ \\
\hline Obyek Wisata gili & 0,611511 & 0,410072 & 0,428571 & 0,209524 \\
\hline Obyek Wisata renang & 0,593525 & 0,374101 & 0,292857 & 0,3 \\
\hline Obyek Wisata mancing & 0,431655 & 0,366906 & 0,271429 & 0,292857 \\
\hline Obyek Wisata selam & 0,410072 & 0,154676 & 0,457143 & 0,204762 \\
\hline Obyek Wisata kemah & 0,402878 & 0,330935 & 0,180952 & 0,285714 \\
\hline Jumlah indeks skor & $\mathbf{2 , 4 4 9 6 4}$ & $\mathbf{1 , 6 3 6 6 9 1}$ & $\mathbf{1 , 6 3 0 9 5 2}$ & $\mathbf{1 , 2 9 2 8 5 7}$ \\
\hline
\end{tabular}

Sumber : data primer - diolah

Koordinatnya pada Matrix Grand Strategy adalah;

Sumbu x : $(2,44964-1,636691)=0,81$,

Sumbu y : $(1,630952-1,292857)=0,33$,

maka koordinatnya adalah $(0,81-0,33)$.

Dengan demikian koordinat indeks terletak pada kuadran pertama, sehingga strategi yang perlu ditempuh adalah strategi agresif.

Grafik Matrix Grand Strategy Wisata Desa Sekotong Barat

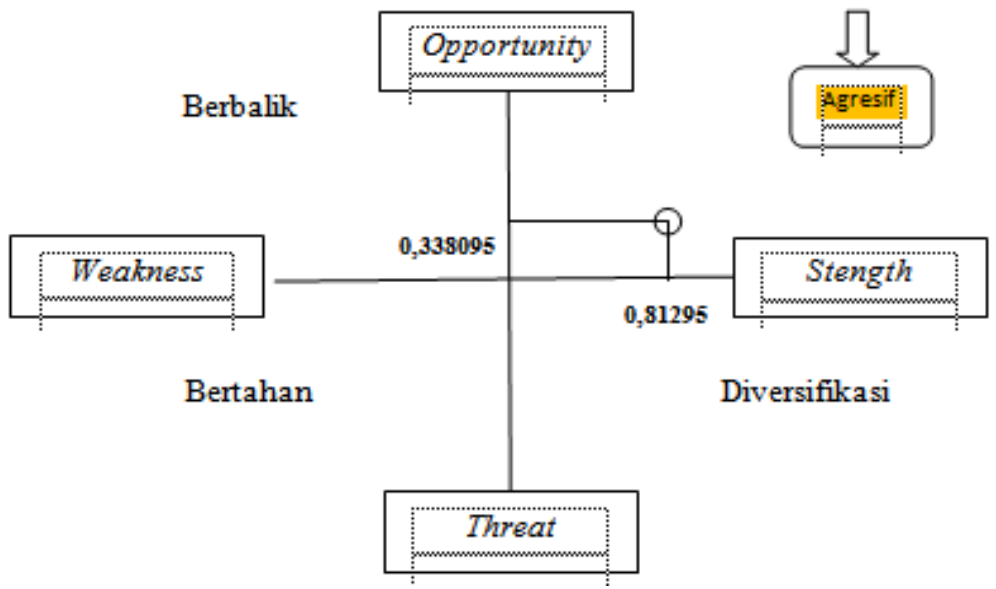

Dalam hal efektifitas dari strategi agresif, konfidensinya rendah. Dengan kata lain, strateginya kurang efektif. Hal demikian diindikasikan oleh angka indeks strategi yang relatif rendah (yaitu, 0,81 dan 0,33 ) karena terkendala oleh banyaknya kelemahan dan ancaman.
Analisa MD pada obyek wisata di Desa Sekotong Barat

a. Obyek Wisata Gili

Ada 4 gili yang menjadi obyek wisata, dengan panorama alam yang indah, tutupan pepohonan yang rindang, pasir putih dan halus, angin laut yang sejuk, dan suasana yang tenang merupakan pesona gili. Antara satu dan 
lainnya relatif berdekatan, dan waktu tempuh dari dermaga ke gili cukup singkat.

Wisatawan terutama domestik ramai berkunjung pada Sabtu-Minggu, masa liburan, dan hari-hari besar/raya. Tidak jarang, rombongan wisman yang berlibur di Bali, singgah di gili beberapa saat, untuk menikmati panorama senja.

Untuk menyebrang menuju ke gili, telah ada dermaga permanen dan tersedia perahu yang selalu parkir di dermaga. Angkutan perahu penyebrangan memiliki organisasi dalam melayani wisatawan. Tempat kuliner, selain ada di daratan, juga tersedia di beberapa gili. Kuliner yang paling umum adalah menu ikan laut. Fasilitas penginapan juga terdapat di salah satu gili, yaitu Gili Nanggu.

Obyek wisata gili juga terdapat di Desa Gili Indah, Kabupaten Lombok Utara. Kelebihan obyek wisata gili Desa Sekotong yaitu suasana alam/lingkungan yang tenang, jauh dari hiruk-pikuk suasana keramaian. Tidak ada strategi tertentu yang dipakai dalam persaingan pasar wisata, sebab masing-masing kemiliki tipikal panorma yang berbeda.

\section{b. Obyek Wisata Renang}

Obyek wisata renang terdapat di beberapa tempat pada gili yang ada. Lokasinya berdekatan dengan daratan. Hanya membutuhkan waktu beberapa menit saat menyebrang. Dengan adanya teluk yang luas dan terlindung dari arus perairan laut, serta gili-gili yang berada dalam teluk membuat arus kecil, perairannya dangkal, airnya jernih dan sejuk, dengan pasir putih dan halus, serta panas matahari terlindung oleh pepohonan.

Segmen pasar terbanyak dari wisatawan domestik dengan beragam segmen umur. Ramai dikunjungi pada hari Sabtu-Minggu, khususnya dalam masa liburan dan hari-hari besar/raya. Pada tempat wisata tersedia kuliner dan jasa angkutan, fasilitas di area wisata dengnan petugas keamanan dan kebersihan.

Keunikan keadaan alam obyek wisata renang di pantai Gili Nanggu dan Gili Sudak seperti yang telah diuraikan, tidak ditemui pada obyek wisata pantai di tempat lain. Dengan keunggulan keadaan alam demikian, obyek wisata renang ini layak menjadi ikon atau brand untuk wisata Desa Sekotong Barat, dengan slogan/branding "renang di Gili Nanggu dan Gili Sudak". Brand ini bukan saja untuk memperkenalkan wisata Desa Sekotong Barat, pula sebagai strategi pemasaran yang efektif.

c. Obyek Wisata Mancing

Bagi wisatawan, tempat ini merupakan favorit. Disamping karena lokasinya (fishing ground) luas, berada di seputaran Teluk Tawun dengan arusnya yang tenang, banyak ikannya, banyak pilihan tempat mancing dan bebas memilih tergantung referensi wisatawan, tidak ada gangguan ombak, area memancing bebas dari gangguan oleh adanya aktivitas pihak lain, serta suasana sekitarnya yang tenang. Semua karakteristik ini merupakan 'persyaratan' standar bagi wisatawan agar dapat menikmati aktivitas memancing.

Biasanya wisatawan yang datang dalam kelompok kecil/ber-grup, dan selama aktivitas memancing mereka akan terpisah satu sama lain. Dukungan yang diperlukan bagi wisata ini adalah jasa penyewaan perahu, pemandu, petugas penyelamatan, dan informasi cuaca. Untuk meningkatkan kunjungan wisatawan, strategi yang dapat dilakukan adalah menyelenggarakan Ferstival Mancing secara periodik/tahunan.

d. Obyek Wisata Selam

Habitat terumbu karang yang terdapat di Teluk Tawun kondisinya masih bagus, dengan jenis yang beragam dan indah, banyak ikan hias di sekitar terumbu karang, arusnya kecil, airnya 
jernih dan tidak terpolusi, dan perairan relatif dangkal.

Umumnya wisatawan berasal dari luar NTB, yang datang karena suatu keperluan (MICE). Mereka datang karena ketertarikan setelah mendapat informasi teman/keluarga yang pernah menyelam di Selat Tawun. Segmen umur wisatawan antara 20-35 tahun.

Dukungan yang diperlukan bagi aktivitas penyelaman adalah ketersediaan sarana pengangkutan, tenaga instruktur, pemandu, penyewaan peralatan, petugas penyelamatan, dan informasi cuaca. Strategi yang dilakukan dalam menghadapi persaingan adalah memberikan layanan terbaik kepada wisatawan. Oleh karenanya perlu memelihara lingkungan dan habitat terumbu karang, penyiapan tenaga kepariwisataan, khususnya instruktur dan pemandu, dan pengelolaan kawasan secara bersama dengan pihak-pihak terkait.

e. Obyek Wisata Kemah

Ada banyak spot atau tempat untuk berkemah (camping ground), yaitu di beberapa gili yang ada, dan di bukitbulit yang mengitari Desa Sekotong Barat. Kondisinya datar, aman dari gangguan hewan/binatang berbahaya, privasi dan jauh dari pemukiman penduduk, pemandangan (view), dan jaminan keamanan dari beberapa pihak (karena ini aktivitas wisata). Aktivitas ini dilakukan secara berkelompok, memerlukan tenda, peralatan masak, transport, dan keamanan. Sementara fasilitas kamar mandi/WC dan air bersih belum tersedia.

Berdasarkan hasil pengamatan dari dua pendekatan (SWOT dan DM) di atas, maka arah pengembangan wisata di Desa Sekotong Barat adalah Wisata Bahari, dengan obyek wisata gili dan renang sebagai unggulannya. Adapun strategi yang diperlukan untuk pengembangan wisata bahari tersebut adalah :
1. Zonasi wilayah perairan pantai Teluk Tawun.

2. Membangun kerjasama yang seluasnya dengan berbagai pihak.

3. Mempromosikan obyek wisata yang ada.

4. Menyediakan berbagai fasilitas dan sarana yang diperlukan di area wisata.

5. Membuat peraturan desa, dan awiqawiq (konsensus) mengenai kelestarian lingkungan, kebersihan, dan keamanan.

6. Penyiapan sumberdaya manusia kepariwisataan.

7. Mengadakan jenis atraksi/obyek wisata baru yang potensial.

\section{KESIMPULAN DAN SARAN}

Kesimpulan penelitian adalah :

a. Arah pengembangan wisata dari Desa Sekotong Barat adalah pengembangan wisatanya wisata bahari.

b. Obyek wisata yang dapat dijadikan wisata unggulan di Desa Sekotong Barat adalah obyek wisata gili dan obyek wisata renang.

c. Grand strategi pengembangan obyek wisata di Desa Sekotong Barat adalah strategi agresif.

Disarankan untuk melakukan dua hal secara simultan, yaitu strategi agresif dan mengatasi kelemahan. Strateginya adalah promosi, dan kerjasama dengan berbagai pihak disertai upaya menyediakan sarana obyek wisata yang diperlukan, dan membuat peraturan lingkup desa terkait dengan pelestarian sumberdaya pariwisatanya.

\section{REFERENSI}

Festivalia, Filma, Mimi Enggriani, Purwanti Dyah Pramanik. 2019. The Impact of Tourism on Village Society. Tourism Research Journal E-ISSN: 2598-9839. 
2019, Vol. 3 No. 2 . https://doi.org/10.30647/trj.v3i2.

Hafida, Siti Hadiyati Nur, dkk. 2019. Analisis Keberlanjutan Desa Wisata (Studi Kasus Desa Wisata Sepakung, Kecamatan Banyubiru, Kabupaten Semarang. Jurnal Ilmiah Pariwisata, Volume 24 No. $3 \quad$ November 2019. https://doi.org/10.30647/jip.v24i3.

Hidayat, Angger, Myrza Rahmanita, Henky Hermantoro. 2017. Community Empowerment in Plempoh Cultural Tourism Village. Tourism Research Journal 2017, Vol. 1 No. 1.

Mappi, S. 2001. Cakrawala Pariwisata. Balai Pustaka. Jakarta.

Valiollahpour, Morteza, Sahar Valiollahpour, Farshid Hasannejad, Seyedeh Maryam Hosseini, Saman Akhavan Niaki. 2014. New Approach to Strategy at the Diamond Model Based on Competitiveness.

International Journal of Scientific Management and Development Vol.2 (6),213-220 June (2014). https://www.academia.edu/83419

91/ New Approach to Strategy at the Diamond Model Based on Competitiveness.

Pitana Dan Gayatri. 2005. Sosiologi Pariwisata. Andi Publisher.

Rangkuti, F. (2009). Analisis SWOT, Teknik Membedah Kasus Bisnis. PT Gramedia Pustaka Utama. Jakarta

Riyanti, Anti , Lia Afriza. 2019. Pengembangan Situ Cipanten Berbasis Ekowisata Di Kabupaten Majalengka. Jurnal Ilmiah Pariwisata, Volume 24 No. 3 November 2019. https://doi.org/10.30647/jip.v24i3

Salam, Febby, Rahmat Ingkadijaya, Hengky Hermantoro. 2018. Strategies to Develop Sawahlunto
Old City in West Sumatera as Tourism Destination. Tourism Research Journal E-ISSN: 25989839. 2018, Vol. 2 No. 2. https://doi.org/10.30647/trj.v2i2.

Sari, Ira Maya, Vienna Artina Sembiring, Haryo Wicaksono. 2019. Pengembangan Wisata Kuliner Berbasis Bahan Pangan Lokal sebagai Dayasaing Di Desa Wisata Sakerta Timur Kabupaten Kuningan Jawa Barat. Jurnal Ilmiah Pariwisata, Volume 24 No. $3 \quad$ November 2019. https://doi.org/10.30647/jip.v24i3.

Satriawati, Zahrotun, Rahmat Ingkadijaya, Sri Sulartiningrum. 2019. Strategy Analysis of Ponggok Rural Tourism Development into Integrated Tourism Area. Tourism Research Journal E-ISSN: 2598-9839. 2019, Vol. 3 No. 1. https://doi.org/10.30647/trj.v3i1.

Sukmana, Eman, Himawan Brahmantyo, Adhi Trirachmadi Mumin. 2018. The Influence of Community Participation, The Role of Village Government, Number of Tourist Visits, and Village Income on Community Welfare in Cibuntu and Citundun Tourism Villages. Tourism Research Journal EISSN: 2598-9839. 2018, Vol. 2 No. 2. https://doi.org/10.30647/trj.v2i2.

Suprina, Rina dan Agrifina Amanda Nathania. 2018. How To Develop Kampung Wisata Batik Pesindon As a Tourist Destination In Pekalongan Through SWOT Analysis. Tourism Research Journal E-ISSN: 2598-9839. 2018, Vol. 2 No. 1. https://doi.org/10.30647/ trj.v2i1.

Susanto, Dwiyono Rudi dan Amin Kiswantoro. 2019. Strategi Pengembangan Hutan Pinus Grenden Berbasis Ekowisata di 
Magelang. Jurnal Ilmiah

Pariwisata, Volume 24 No. 3

November 2019.

https://doi.org/10.30647/jip.v24i3.

Vitriani, CH. Dian, Djoko Sudibyo,

Henky Hermantoro. 2017. Socio-

Economic Impacts of Tourism

Development in Rural Area of

Sembalun East Lombok West

Nusa Tenggara. TRJ Tourism

Research Journal 2017, Vol. 1 No.

1.

http://trj.stptrisakti.ac.id/index.ph

$\mathrm{p} / \mathrm{trj} / \mathrm{article} / \mathrm{view} / 2 / 1$. 